\title{
Platform for the information network of the economic reactivation program of the TecNM campus San Martín Texmelucan
}

\section{Plataforma para la red informativa del programa de reactivación económica del TecNM campus San Martín Texmelucan}

MORALES-ZAMORA, Vianney†*, PAREDES-XOCHIHUA, María Petra, LÓPEZ-MUÑOZ, Jesús and PADILLA-LEÓN, Jonathan

\author{
Instituto Tecnológico Superior de San Martín Texmelucan, Road to Barranca de Pesos S I San Lucas Atoyatenco San \\ Martín Texmelucan, Puebla. C.P. 74120, Mexico.
}

ID $1^{\text {st }}$ Author: Vianney, Morales-Zamora / ORC ID: 0000-0002-1181-825X, Researcher ID Thomson: S-6627-2018, CVU CONACYT ID: 308547

ID $1^{\text {st }}$ Co-author: Maria Petra, Paredes-Xochihua / ORC ID: 0000-0003-1753-2313, Researcher ID Thomson: S-69912018, CVU CONACYT ID: 298117

ID $2^{\text {nd }}$ Co-author: Jesús, López-Muñoz / ORC ID: 0000-0002-3414-0891, Researcher ID Thomson: S-6861-2018, CVU CONACYT ID: 947242

ID $3^{\text {rd }}$ Co-author: Jonathan, Padilla-León

DOI: $10.35429 / J L D E .2020 .7 .4 .40 .42$

Received July 25, 2020; Accepted December 30, 2020

\begin{abstract}
Web system that allows small entrepreneurs in the San Martín Texmelucan Region and its surroundings to register information about their businesses, such as their address, business hours, information on the products they sell, data from their social networks, the types of shipments and deliveries. In order to promote the information to the outside public, and among the merchants themselves, to know who their suppliers may be. Searches are carried out according to the lines in which businesses were registered, and are presented to users according to opening hours. The project was born out of the need to offer a web platform in which businesses in the San Martín Texmelucan region can register online their products or services that they offer, thus allowing the economy in this region to be reactivated, to face the COVID19 pandemic, which affected all sectors and economic sectors
\end{abstract}

Platform, Reactivation, Informative

\begin{abstract}
Resumen
Sistema web que permite a los pequeños empresarios de la Región de San Martín Texmelucan y sus alrededores, el poder registrar información de sus negocios como lo es su dirección, horarios de atención, información de productos que venden, datos de sus redes sociales, los tipos de envíos y entregas. Con el fin de promocionar la información al público exterior, y entre los mismos comerciantes conocer quiénes pueden ser sus proveedores. Las búsquedas se realizan de acuerdo a los giros en los que fueron registrados los negocios, y se presentan a los usuarios de acuerdo al horario de apertura. El proyecto nació de la necesidad de ofrecer una plataforma web en la que los negocios de la región de San Martín Texmelucan puedan registrar en línea sus productos o servicios que estos ofrezcan, permitiendo así se vaya reactivando la economía en esta región, para hacer frente a la pandemia del COVID-19, que afecto a todos los sectores y giros económicos
\end{abstract}

Plataforma, Reactivación, Informativa

Citation: MORALES-ZAMORA, Vianney, PAREDES-XOCHIHUA, María Petra, LÓPEZ-MUÑOZ, Jesús and PADILLALEÓN, Jonathan. Platform for the information network of the economic reactivation program of the TecNM campus San Martín Texmelucan. Journal-Labor and Demographic economic. 2020. 4-7:40-42.

\footnotetext{
* Correspondence to Author (Email: vimoza@hotmail.com)

$\dagger$ Researcher contributing first author.
} 


\section{Introduction}

The COVID 19 pandemic is forcing us to accelerate the imminent changes facing society; The current context generates uncertainty and concern in merchants who obtain their economic resources every day, and whose economic activity depends on the activation of schools, and the flow of people taking to the streets.

With the passing of the coronavirus pandemic, the National Technological Institute of Mexico, San Martín Texmelucan campus, is working on an economic reactivation program in the region, providing advice to small entrepreneurs to promote social and economic development in Puebla [1].

This support mechanism for microentrepreneurs is provided in a personalized way to help the growth of their company or business idea, in addition to reducing the effects of the economic crisis caused by the global pandemic.

The project was born out of the need to offer a web platform in which businesses in the San Martín Texmelucan region can register online the products or services they offer, thus allowing the economy in this region to be reactivated, to face the COVID-19 pandemic, which affected all sectors and economic sectors. Therefore, the platform allows the representatives to register the business data, location, photographs, products, schedules, types of delivery, among other aspects that were detected during the analysis that was carried out in order to develop the system. Which was developed following the SCRUM methodology, where partial and regular deliveries of the final product are made [2].

\section{Methodology}

The SCRUM software development methodology includes the phases: Planning, Execution and Adaptation.

\section{Planning phase}

In this phase, the interviews are carried out to obtain the functional and non-functional requirements of the System, subsequently a list of activities is prepared and organized according to priorities and before being assigned to the work team, they are set in Sprint. In this phase, the tools, languages and software to be used are also selected, in this case balsamiq, dia, sublimetext, Mysql, php, Html 5, css3, boostrap, jquery, ajax, Json and Javascript will be used.

\section{Execution Phase}

In this phase, the work team begins to develop its activities, which include the low-fidelity screens, the use case diagrams, the design and development of the database, as well as the development of the high-fidelity screens. fidelity. And all this in considerable advancements called Sprints, which are presented to the customer for their feedback.

\section{Adaptation Phase}

6 Sprints were developed, in the first sprint the design of the platform that includes the low screens and the database design was presented, in the second sprint the first high-fidelity screens and the development of the database were presented. Data, in the third sprint it includes the connection with the database and the management of users, in the fourth sprint it contemplates the session of the administrator user, in the fifth sprint the interfaces of the business owner user and the client user are shown. And finally in the sixth sprint the feedback from the platform is presented.

\section{Results}

With this project we work to promote the economic development of the San Martín Texmelucan region and with the support of students and teachers; So far 138 businesses registered on the platform are supported. Figure 1 shows the platform's home page, which displays the logos of the educational institution, a menu of options to consult products and services, as well as the start of the session, when business owners register a business, they incorporate two images, one that is presented in a carousel from the beginning and another that is shown as a result of the consultation of a product or service. 


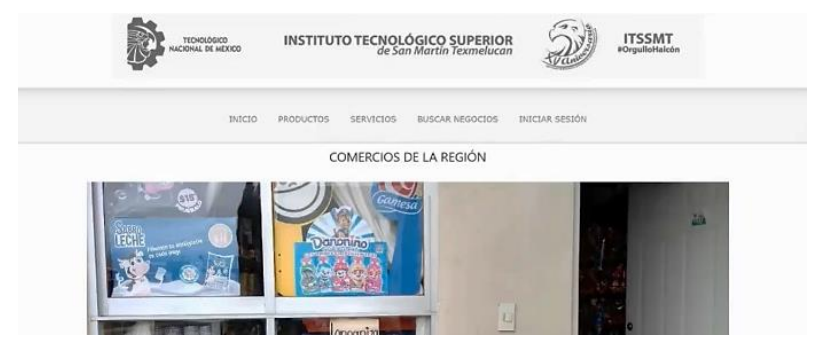

Figure 1 Starting screen

The search for products and services is carried out using the type of transfer as shown in figure 2 , and the result of this is the business information, which includes hours, types of payment, address, telephone number and social networks, etc, as seen in figure 3 .

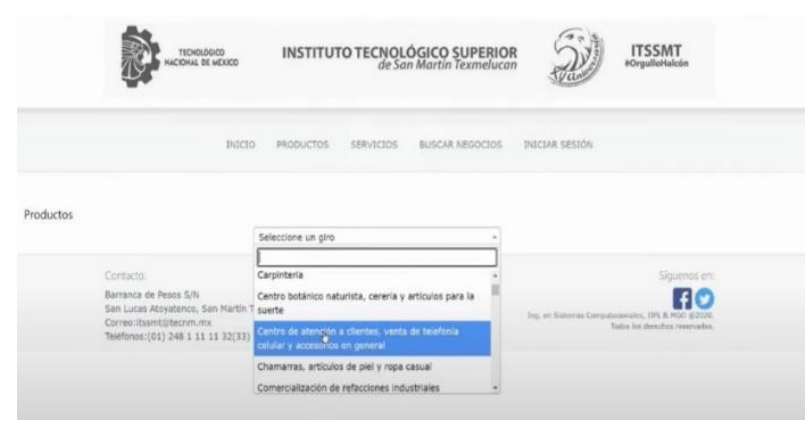

Figure 2 Product Search

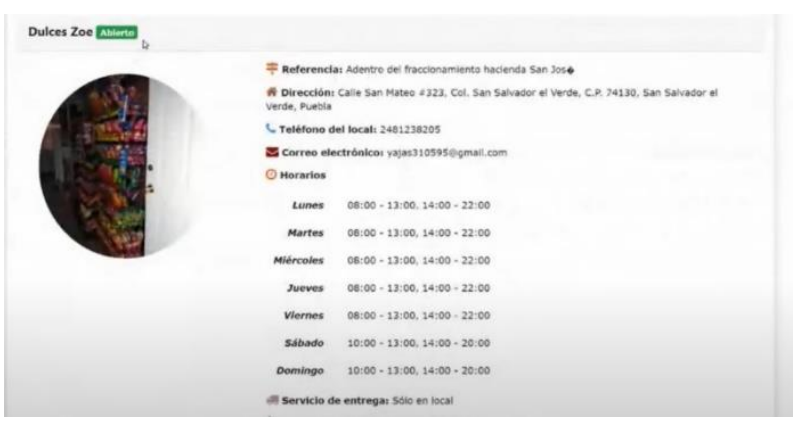

Figure 3 Example of product search result by turn

In the session of an administrator user, the registered information of users, money orders, owners and businesses can be viewed, with the option to insert, edit, and delete data as shown in Figure 4.

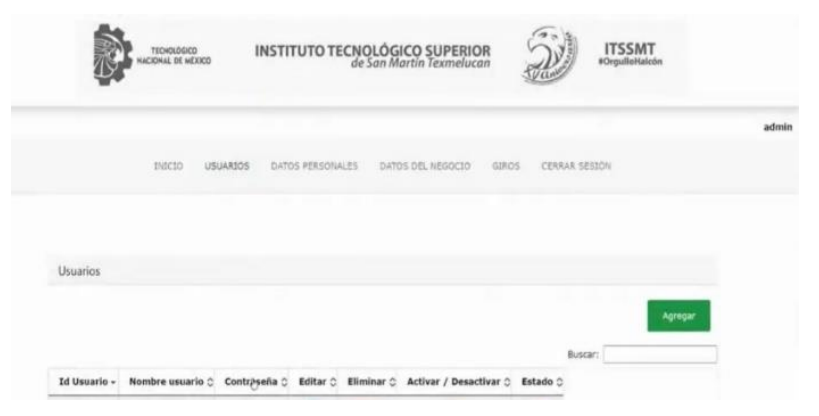

Figure 4 Options in the administrator user session.
In the business owner user session as presented in Figure 5, you can add the owner and business information, which includes the address, telephone number, opening hours, social networks and information on products and / or services. what offer, as well as an option to find supplies for your business.

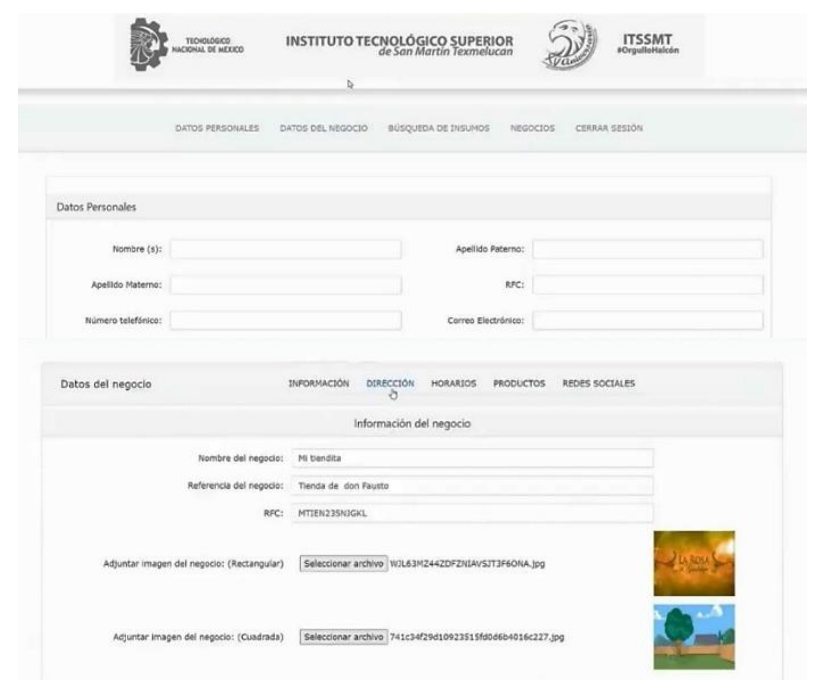

Figure 5 Options in the business owner user session.

\section{Conclusions}

The System has served to publicize small businesses in the San Martín Texmelucan region, and according to the survey carried out on October 20, 2020 to business owners, their sales have increased by 30 to $50 \%$, after registering your business on the platform.

\section{References}

[1] TecNM (2020). Lanza TecNM programa de reactivación económica regional. Consultado el 20 de Agosto de 2020. Recuperado de: https://www.tecnm.mx/?vista=noticia\&id=8 65

[2] Que es SCRUM (s.f.). En proyectos Agiles. Consultado el 20 de junio de 2020. Recuperado de: https://proyectosagiles.org/que-es-scrum/

[3] Boostrap (2020). Components, Consultado el 10 de junio de 2020. Recuperado de: https://getbootstrap.com/docs/4.5/component s/alerts/

[4] W3school (2020). CSS, Consultado el 10 de junio de 2020, Recuperado de: https://www.w3schools.com/css/ 